The 1937 budget predicted a deficit of $\$ 35,000,000$ while recommending that more than that amount be spent on armaments. This caused the socialist rallying cry of "Disarmament with a surplus".

\title{
Paragraph 5.
}

In 1935 Conservative Prime Minister Richard Bennett's government enacted "New Deal" legislation aimed at easing the effects of the Depression. This legislation included the Employment and Social Insurance Act, the Natural Products Marketing Act and the Minimum Wage Act. The nine provinces protested that these Acts were an infringement on provincial jurisdiction as defined by the British North America Act. In January 1937 the Judicial Committee of the Privy Council in London found in the provinces' favour, ruling almost all the legislation ultra vires.

\section{Notes}

1. The letter is currently in the possession of A.J. Hobbins, Humphrey's literary executor, but will eventually be donated to the McGill University Archives.

2. See F.R. Scott "Impressions of a visit to the USSR" Canadian Forum vol. 15 (December, 1935) pp. 382385. In this Scott stated "...the present dictatorship..involves tactics that positively hinder the attainment of socialism. Despite these qualifications I came away believing that the objectives of the revolution will eventually be achieved."

3. For a fuller description of the question of Scott, Morgan and the Board of Governors, see Stanley B. Frost, McGill University for the Advancement of Learning, Vol. 2 (Montreal: McGill-Queen's University Press, 1984) pp. 193-197.

\section{McGill Law Library Moves into Cyberspace(s)}

\author{
By Kate Williams \\ Director, University Relations Office
}

\begin{abstract}
"To leave no stone unturned" is the felecitous phrase from Euripedes engraved on the stone exterior of the new McGill law library, which was inaugurated on September 17, 1998 in the presence of Quebec's LieutenantGovernor Lise Thibault and hundreds of guests. "Given the years of effort to raise funds for the building, it is an apt reminder of what the University must do to sustain its margin of excellence and international reputation," says McGill Principal Bernard Shapiro. Hampered for decades by totally inadequate space while the student body increased by $50 \%$ and legal scholarship exploded, the old law library was considered one of the worst in Canada. Now, thanks to more than 300 donors, the new library welcomes users into a startingly different environment, one designed to bridge the past and the future in radical, sometimes light-hearted, sometimes sobering ways. The architect is Dan Hanganu, considered one of Quebec's hottest architects.
\end{abstract}

Named for major benefactor and graduate Nahum Gelber (B.A. '54, BCL ' 57 ), the $\$ 11.5$ million structure was made possible by large and small contributions from individual graduates, law firms, foundations and friends of the Faculty. "We're thrilled that so many people supported us," says Dean Stephen Toope. 
With a multipurpose atrium linking it to Old Chancellor Day Hall on Peel Street, the Nahum Gelber Law Library is described in a commemorative brochure as a "suitable consort [for surrounding mansions], with its dark seriousness, dignity and occasional touches of whimsy." Hanganu himself has said it is "a box - a simple box" conceived to reveal inward beality and gravity of purpose "for people who come to read and learn - and grow."

According to Toope, the Library is, however, much more than a box - it is a catalyst for the Faculty which, poised to mark its $150^{\text {th }}$ anniversary throughout the 1998-99 academic year, is plunging into cyberspace with remarkable enthusiasm. Every one of its 350 work stations, for example, is wired for laptops and connected to the Internet, with user-friendiy technology support "instantly visible as you walk in," he notes. Toope and Law Librarian Robert Clarke point out that students have been deeply involved in the project, influencing the Library's design to an exceptional degree and helping to ensure that it is the first completely barrier-free library in the entire University.

Implementing the Gaculty's new curriculum will continue the momentum forward during 1998-99 and beyond. "Our recent revisions are dramatic, but they're based or wide consultation and, in my view, show tremendous courage and creativity. Students will have more choice, and the two great legal systems of the Western world, common law and civil law, will truly illuminate one another, almost in a dialogue, right from the first year of study," says the Dean.

\title{
Walter Hitschfeld Geographic Information Centre
}

\author{
By Carol Marley \\ Information Services Librarian
}

November 14, 1997 saw the official opening of the new Walter Hitschfeld Geographic Information Centre (GIC). Occupying the entire fifth floor of Burnside Hall, the GIC combines the former Walter Hitschfeld Environmental Earth Sciences Library with the new GIC Computer Lab devoted primarily to geographic information systems (GIS) activities. The library, without walls, serves as a repository of digital geographic data (in addition to traditional maps and atlases, as well as collections in the disciplines of cartography and GIS). The lab provides the means of analyzing and mapping these data with GIS software and state-of-the art computer facilities. The new GIC cost over $\$ 280,000$, with generous contributions from the Dean of Science, Alan Shaver, and the Director of Libraries, Frances Groen.

This exciting new partnership between the Faculty of Science and the McGill University Libraries has enabled the University to bring together a team of GIS "experts" whose mission is to further the cause of GIS literacy at McGill. There are approximately 60 computers, many of these being Pentium 200 MMXs with 17 inch monitors attached to a new file server and Lexmark colour laser printer. Digitizing and scanning equipment is also available. There is an interactive classroom for teaching GIS, data retrieval and Web navigation. The instructor's computer is permanently connected to a SONY computer projection system. GIS software includes ESRI's Arcview 3.1, and accompanying Network Analyst and Spatial Analyst modules, Map Info 4.1 and Idrisi 4 for Windows.

The GIC is open seven days a week in term time. Graduate students in the Department of Mathematics, Geography and Atmospheric and Oceanic Sciences, as well as selected undergraduates, have the additional advantage of 24 hour access using a swipe card and PIN system.

The library's Web page gives details on collections and services, 